\title{
Ivanna Blazhkevych about the development of pre-school education as a factor in building a strong state
}

\author{
Hryhorii Tereshchuk ${ }^{1}$, Oleksandra Yankovych $^{2}$, Kateryna Binytska ${ }^{3, *}$, Olena Binytska ${ }^{3}$, and Iryna Kuzma $^{4}$ \\ ${ }^{1}$ Ternopil Volodymyr Hnatiuk National Pedagogical University, Department of Service Industry, Technologies, Occupational Health \\ and Safety, Ternopil, 46027, Ukraine \\ ${ }^{2}$ Kujawy and Pomorze University in Bydgoshch, Department of Early Education, Special Pedagogy, Resocialization, 85-023 \\ Bydgoshch, Poland \\ ${ }^{3}$ Khmelnytskyi Humanitarian-Pedagogical Academy, Department of Pedagogy, Khmelnytskyi, 29013, Ukraine \\ ${ }^{4}$ Ternopil Regional Communal Institute of Postgraduate Pedagogical Education, Department of Pedagogy and Psychology and Inclusive \\ Education, Ternopil, 46027, Ukraine
}

\begin{abstract}
The activity and creative work of Ukrainian activist, writer, teacher Ivanna Blazhkevych (1886-1977) in the context of the development of pre-school education as a factor of strengthening the state have been thoroughly investigated in the article. For the first time the periodization of main stages of life and development of cultural-educational and scientific ideas of Ivanna Blazhkevych were substantiated in the article. The basic directions of pedagogical and cultural-educational activity and creativity of I. Blazhkevych have been clarified: pre-school-pedagogical (organization of pre-school institutions; substantiation of methods of pre-school education; determination of requirements for kindergarteners-educators); educational (participation in the elimination of illiteracy), ethnographic (collection of ethnographic material: recording folk songs, legends, sayings); national-patriotic (preservation of national traditions, mother tongue); guardianship (assistance to local war victims, prisoners of war, establishing orphanages for children); economic (founding cooperatives; working as a director of the district union of cooperatives in Ternopil), literary (writing books for children).
\end{abstract}

\section{Introduction}

\subsection{Problem statement}

The need for modernization of the pre-school education system in Ukraine in the context of European integration processes prompts a comprehensive study of the genesis of foreign educational systems and technologies in order to implement positive ideas in modern institutions. At the same time, the history of Ukrainian pre-schooling, when the genesis of kindergartens was influenced by progressive foreign reform pedagogy and domestic concepts and approaches to education, is worth studying. These processes took place in Eastern Galicia at the end of the $19^{\text {th }}-$ beginning of the $20^{\text {th }}$ century. On the one hand, the kindergarten folk traditions of pre-school pedagogy were implemented in children's "okhoronky" (until 1903, so-called kindergartens in the region; laterzakhoronky); on the other hand, European achievements of pre-school education were actively used.

Among the famous figures of Ukrainian pre-school pedagogy, which is not sufficiently popularized in modern educational books for students, it is necessary to mention the name of the famous educator and writer, the founder of children's "zakhoronky" Ivanna Blazhkevych, who almost a century ago expressed the view that "the path to "clear gate" lies through the education of the people, through "the construction of national life, and it must be started from the youngest generation, and this process is continuous" [1, p. 2].

Although Ivanna Blazhkevych is the founder of children's institutions, she substantiated the methodology of pre-school education, defined the requirements for kindergarten teachers, but her activity and creativity is reflected only in a few publications. At the same time, the study and popularization of the figure of Ivanna Blazhkevych in the context of pre-school education development is one of the important factors for building quality pre-school education in our country and hence its economic progress.

\subsection{Analysis of recent researches and publications}

Analysis of scientific works, textbooks, reading books on the history of pre-school education, monographs, dissertation researches showed that to date in the national historical-pedagogical science there are only single attempts to investigate and summarize the scientific-pedagogical and literary legacy of Ivanna Blazhkevych despite her significant role not only in the development of pre-schooling, but also in the Ukrainian region.

Ivanna Blazhkevych, as well as Nataliia Kobrynska and Kostiantyna Malytska, are the founders of pre-

\footnotetext{
* Corresponding author: rfn.yz87@gmail.com
} 
school education in Eastern Galicia, these activists started the national pre-school education.

Studying historical-pedagogical sources shows that some theoretical and practical problems of pre-school education in the pedagogical thought of Ukraine in the second half of the $19-20^{\text {th }}$ centuries have been analyzed in a number of researches (N. Salyha [2], I. Uliukaieva [3], B. Melnychuk [4], V. Khoma [4], O. Hanusyn [5]). However, the monograph of Z. Nahachevska "The Ukrainian Pre-Schooling in the Educational Space of East Galicia" (end of the $19^{\text {th }}$ century - 1939) is especially distinguished by the soundness of representation of this issue. Among a number of prominent educational figures of that time Z. Nahachevska singled out the figure of I. Blazhkevych [6], described her recommendations on the establishment and organization of seasonal kindergartens in the early 1930-s, in particular, stating: "The book, identified by the author as a manual, consists of the introduction and 13 chapters. The basis of the manual was the experience of working with pre-school children by I. Blazhkevych herself' [7, p. 136].

The works of I. Rutylo [8], M. Chorna [9] deal with highlighting of pedagogical achievements of the Ukrainian activist, writer, teacher I. Blazhkevych. The scientific researches of I. Kuzma, who revealed the role of I. Blazhkevych in the history of media education, are characterized by the novelty, because through the development of aesthetic tastes the writer influenced the formation of media literacy of pre-schoolers at the time when there were no special media educational terms $[10$, p. $30 ; 11$, p. 108].

Therefore, there are only a few scientific works in which the pedagogical heritage and contribution to the genesis of pre-school pedagogy by I. Blazhkevych are fragmentally reflected. However, we have not identified a comprehensive scientific study of the outstanding figure of Ivanna Blazhkevych in the context of the development of pre-school education and pedagogy, both past and present; her ideas that are worth reviving. At the same time, the pedagogical articles and books of the writer of the early $20^{\text {th }}$ century of pre-school education are still quite interesting in the study of the historical development of pre-schooling, and remain relevant in pre-school theory and practice.

Objective of the research: on the basis of retrospective analysis to thoroughly study the creativity of Ivanna Blazhkevych as for the development of preschool education as a factor in building a strong state and to determine the possibilities of realization of perspective ideas in the modern Ukrainian pre-schooling.

\section{Material and methods}

Research-bibliographic (for searching and systematizing sources), historical-retrospective (for analyzing the content and directions of pedagogical and culturaleducational activity I. Blazhkevych in historical retrospective), comparative (for comparative analysis of pre-school education in Eastern Galicia, creativity of the founders of pre-school education), biographical (for study the views and ideas of Ukrainian public figures, scientists, writers as for the development of theory and practice of pre-school education in specific sociopolitical conditions); prosopographic (for creating comprehensive characteristic of a prominent activist I. Blazhkevych), prognostic (for determining the possibilities of implementing of I. Blazhkevych's ideas in modern pre-school institutions).

\section{Results}

In Galicia, the ideas as for the social upbringing of small children emerged at the same time as the development of public pre-school education in Western European countries (the prerogative belongs to the German educator F. Froebel), and the emergence of appropriate prerequisites in the industrial production, which required new workers, including women, so a woman could no longer take care for the children who needed it. In addition to manufacturing, there have been social changes. We mean the emancipation of society. With the expansion of ideas about the outside world, access to education, women came from their private family world into the public world: they sought to get education, to acquire a profession. Of all the professional categories, women were most likely to pursue a career in schooling and literature [5, p. 128].

Therefore, it was precisely against the background of socio-economic factors that proposals were made to create pre-school establishments.

It is known that in 1848 the peasant Ivan Zaluzhnyi from Kamianka Volynska at the meeting of the Main Russian Council for the first time proposed the creation of Ukrainian pre-school establishments, but at that time this proposal was not supported [12, p. 19].

At that time, Polish and German charity communities were already developing in the Ukrainian territories, which together with the church, private individuals founded the gardens of angels, pre-school establishments, elementary pre-schools, zakhoronky, a day nurseries, Froebel's nurseries for children from rich families. Already in 1888 in Galicia there were 25 "zakhoronky" and Froebel's nurseries [12, p. 25].

Galician intelligentsia, rural communities, advocating the teaching of children in the Ukrainian language, considered the opening of national pre-school establishments and primary schools the first step in addressing this issue.

Theoretical and methodological basis for the development of pre-schooling in Eastern Galicia was the educational ideals, views and cultural-educational activity of Mykhailo Hrushevskyi, Ivan Franko, Oleksandr Dukhnovych, Nataliia Kobrynska, Kostiantyna Malytska, Omelian Partytskyi, Hryhorii Vretsiona, Ivan Petryshyn and other progressive figures.

The pedagogical foundations of the educational work of the first kindergartens were developed under the influence of Western Ukrainian theory and practice of social education, which mainly absorbed the achievements of Friedrich Froebel, Maria Montessori, Ovid Decroly and used their provisions on the purpose of pre-school education. At the same time, the achievements and acquisitions of the national experience 
of family education, which was based on Ukrainian ethno-pedagogy and moral principles of Christianity, were realized.

Considerable contribution to the development of preschool education in Galicia made educators whose names and activity are little known to the contemporaries: I. Bartoshevskyi, I. Blazhkevych, M. Hrushevska, N. Kobrynska, V. Kotsovska, K. Malytska, I. Petryshyn, D. Shukhevych-Starosolska and others.

Due to their activities in the field of theory and practice of pre-school education, the purpose of the first kindergartens (1909) was defined as the protection of children from the effects and dangers of the environment; education of children, implementation of national patriotic and religious education [12, p. 59].

Ivanna Blazhkevych's figure is characterized by the diversity of activities and achievements among the theorists and practitioners of pre-school education. She is known in the Ternopil region primarily because she is a native and has spent there all her life. The regional archive of Ternopil region has a fund that holds documents related to work for the Ukrainian people by I. Blazhkevych. It is there that stores Manuscripts of Essays: About Children and Parents [13].

On the basis of the holistic and systematic analysis of pedagogical, cultural and educational activity and creativity of I. Blazhkevych, the main stages of which are shown in Table 1.

Table 1. Main stages of life and development of culturaleducational and scientific ideas of Ivanna Blazhkevych

\begin{tabular}{|l|l|l|}
\hline No & $\begin{array}{l}\text { Name of the } \\
\text { stage, years }\end{array}$ & \multicolumn{1}{|c|}{ Main events } \\
\hline 1. & $\begin{array}{l}\text { Educational- } \\
\text { ethnographic } \\
\text { (1886-1912) }\end{array}$ & $\begin{array}{l}\text { Born on October 9, 1886 in the village of } \\
\text { Denysiv Kozlivskyi (Kozivskyi district) } \\
\text { in Ternopil region in the family of the } \\
\text { village teacher Omelian Borodiievych. } \\
\text { There were 4 children in the family. } \\
\text { Ivanna's sister's name is Melaniia. } \\
\text { Brothers - Ostap and Yevhen. } \\
\text { Receiving primary education in the } \\
\text { village of Denysiv. Personal acquaintance } \\
\text { with I. Franko in 1894. }\end{array}$ \\
\hline 2. & $\begin{array}{l}\text { Educational- } \\
\text { guardian } \\
\text { (1912-1928) }\end{array}$ & $\begin{array}{l}\text { Studying at the seven-year high school } \\
\text { named after Queen Jadwiga in Ternopil. } \\
\text { Active collection of ethnographic } \\
\text { material: recording of folk songs, } \\
\text { legends, proverbs. } \\
\text { Combining self-education with active } \\
\text { ocial activity. } \\
\text { Organization in 1904 in the village of } \\
\text { Denysiv of the women's section of the } \\
\text { "Circle of Ukrainian Girls" (1904-1911) } \\
\text { (cooking courses, systematic lectures of } \\
\text { hygiene for all segments of the } \\
\text { population in order to eliminate illiteracy } \\
\text { in the countryside) } \\
\text { The first literary attempts (1908). } \\
\text { In 1909, at the First All-Ukrainian } \\
\text { Agricultural Exhibition in the town of } \\
\text { Stryi, she was awarded a diploma and a } \\
\text { silver medal for her ethnographic } \\
\text { collection. }\end{array}$ \\
\hline
\end{tabular}

\begin{tabular}{|c|c|c|}
\hline No & $\begin{array}{l}\text { Name of the } \\
\text { stage, years }\end{array}$ & Main events \\
\hline & & $\begin{array}{l}\text { Perception of I. Franko's idea of the } \\
\text { economic uplift of peasants through } \\
\text { agricultural unions. } \\
\text { Teaching activity with her husband } \\
\text { teacher in the village of Subotiv, village } \\
\text { of Zalukvy in Stanislav region. } \\
\text { Participation in the elimination of } \\
\text { illiteracy, enhancement of the general } \\
\text { culture in the countryside. } \\
1914 \text { - acting as the headmaster of school } \\
\text { in the village of Zalukva. } \\
\text { Assisting local war victims, prisoners of } \\
\text { war, establishing orphanage shelters for } \\
\text { children. Description of military misery } \\
\text { in the book "Woman on the Battle Line". } \\
\text { Studying at the Lviv Teacher's Seminary. } \\
\text { Activity in the society of child protection } \\
\text { and youth care. Teaching at school. } \\
\text { Establishment of reading rooms, dramatic } \\
\text { circles. }\end{array}$ \\
\hline 3. & $\begin{array}{l}\text { Integration } \\
\text { (1929-1977) } \\
\text { combination of } \\
\text { pre-school- } \\
\text { pedagogical } \\
\text { socio-economic } \\
\text { and literary } \\
\text { activity }\end{array}$ & 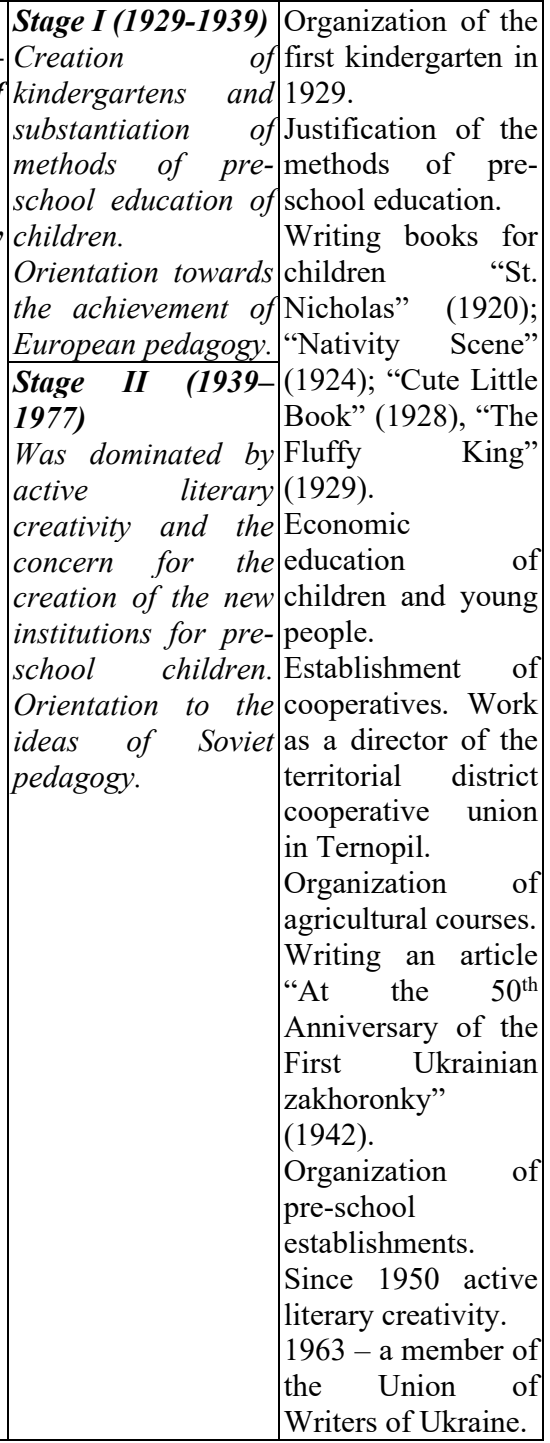 \\
\hline
\end{tabular}

So, the main directions of pedagogical and culturaleducational activity and creativity of I. Blazhkevych are the following: pre-school-pedagogical (organization of pre-school institutions; substantiation of methods of preschool education; determination of requirements for 
kindergarten educators); educational (participation in the elimination of illiteracy), ethnographic (collection of ethnographic material: recording folk songs, legends, sayings); national patriotic (preservation of national traditions, mother tongue); guardianship (assistance to local war victims, prisoners of war, establishing orphanages for children); economic (founding cooperatives; work as a director of the Union of cooperatives in Ternopil), literary (writing books for children).

Thus, Ivanna Blazhkevych is known as a children's writer. Her poems, stories, and nonfiction articles of her time were published by progressive Galician newspapers and magazines. The creative activity and public work of Ivanna Blazhkevych were supported by Olha Kobylianska, Uliana Kravchenko, Tymofii Borduliak, with whom the writer was on friendly terms. For children, Ivanna Blazhkevych began writing in the 1920s. In the publishing house "Child's World" were published one by one her plays, stories, poems: "St. Nicholas in 1920", "Taras at the Deacon", "Deed in Honor of Taras", "Vertep", "Sweet Little Book", "Fluffy King", "On Mother's Day", "Ivas-Kharacternyk", "Narration" and others. After 1939, Ivanna Blazhkevych was actively involved in the creation of the Denysiv seven-year school, kindergarten, worked as a teacher, and took care of the cultural transformations in the village. New children's books by the writer "Podolianochka" (1958), "Arrival of a Stork" (1971), "Is There Something Brighter in the World" (1977), "Swallows" (1986), "In Kindergarten" (1993) and others [14].

Today, I. Blazhkevych's poems for children are often retold by children and parents, in particular, "Little Ukrainian Girl" "Is There Any Light in the World?" I. Blazhkevych spread the idea that the power of state formation is in education, and it is necessary to start education from the youngest age. The prominent educator has made other important steps towards improving the lives of Ukrainians: she is the founder of the cooperative movement in Ternopil and Podillia region.

At the same time, the figure of Ivanna Blazhkevych as a theoretician and practitioner of pre-school education in Eastern Galicia (beginning of the twentieth century) deserves attention, taking into account the urgency and the low level of popularization. In 1929, she organized in Denysiv, her native village, the first pre-school institution. Anna Zharska was the headmistress; Ivanna Blazhkevich was the curator. The medical care was given by Dr. Ivan Yavorskyi, a doctor from neighboring Kupchyntsi. The singing was taught by Ivan Blazhkevych, a retired teacher. There were 48 children who paid for their education. 6 children were educated free of charge, based on the decision of the department. The average number of children attending the kindergarten was 30-33 people [8, p. 107].

The payment was 5 zloty per month. The children's mothers gave $1 \mathrm{~kg}$. of cereals or flour a week, 1 loaf of bread for 10 days, and each child brought with them a daily bottle of milk (1 liter) [8, p. 107].
Work in the kindergarten began at 6 o'clock. a.m. The children came without breakfast. At 8 o'clock they drank milk, at 10 o'clock they ate bread with butter or honey, at 12 o'clock they had lunch: thin gruel or dough with milk. Once a week there was lunch with meat.

From $14^{00}$ to $15^{00}$ there was a "dead" hour in the kindergarten, with full silence. The children slept in separate beds [8, p. 107].

At $16^{00}$ there was light lunch, consisting of milk and bread. There was self-service in the kindergarten. A person on duty appointed "matchmakers", "bridesmen" and "headman", who supervised the order, making sure that no one was hurt.

In 1929 the kindergarten was headed by Nusia Zharska, who became a favorite of the whole village. She loved all the children as relatives, taught them the games, fun and songs that were heard throughout the village. Such care of the pupils was appreciated by the mothers of children from the kindergarten and, as a gift, they bought her a wristwatch with the words: "From grateful mothers". Funds for the purchase of the watch were collected by the mothers of children [8, p. 108].

At the end of the education in kindergarten there was a children's holiday, with a program performed by the children: they sang, recited poems, and danced in the round, taught by Nusia Zharska. The dwellers of the village Denysiv gathered at the solemn event and welcomed every performance of the holiday program with the warm applause [8, p. 107].

Following the example of the village Denysiv the kindergartens in the nearby villages were founded. For kindergartens, the Society for the Protection of Children and Youth Welfare in Lviv trained headmistress in courses in the city of Lviv and in other cities [8, p. 108].

Recommendations for the founding and organization of seasonal kindergartens in the early 1930-s were reflected in the already mentioned work of Ivanna Blazhkevych, "Kindergarten in the Village during Summer Work".

The most valuable are the recommendations approved by the author and analyzed by Z. Nahachevska on the methods of lessons with children in kindergarten. Given that "service to the child is service to God", I. Blazhkevych considered interest as the main impetus for the activities and entertainment of children. She rejected the detailed work planning for each day: in her opinion, " $\ldots$ the teacher teaches the children what they are interested in" [6, p. 137].

The pedagogue and the children's writer considered the innate tendency to speak as the basis for the spiritual development of the child. That is why a lot of attention was given to the use of the native word - poems, stories, fables, dramatizations. "The science of poems" is the most elaborated in the manual. Not only scientifically justified requirements for the selection and educational orientation, methods and techniques of work with poetic works, but also created by I. Blazhkevych or skillfully selected texts of poems for formation of high patriotic feelings of a child are of great importance ("Prayer of the Ukrainian Child", “Who am I?") [13; 12, p. 137].

For the development of sensations I. Blazhkevych offered exercises to distinguish between colors, size, 
condition, body temperature, etc. The special attention was paid to games, motors, fun, and the author presented their models from S. Rusova's work "Theory and Practice of Pre-School Education", collections of A. Zhyvotyk, manual of O. Sukhoverska and others. At the same time, I. Blazhkevych considered it as illadvised decision to introduce Ukrainian children into the alien and distant nature of the games offered by the Polish textbooks $[11 ; 12$, p. 138].

The guide contains tips for conducting "free" conversations, viewing and describing pictures, teaching children singing, music. In our opinion, it can still be used today in the work with pre-school children.

The logical conclusion of the work on the creation of organizational-methodological foundations of seasonal kindergartens was the publication by the General Board of the Native School Society of the Instruction entitled "How to Found and Maintain Kindergartens", which appeared in Lviv in 1932. Prepared based on the accumulated theoretical and practical experience of Ukrainian seasonal kindergartens, this instruction was intended as an official instruction from the leading organization that took over the leadership and control over the activities of all types of Ukrainian pre-school institutions. It revealed the main reasons and needs for opening kindergartens, the procedure for their establishment, contained instructions for the kindergarten teacher, requirements for kindergarten hygiene, nutrition for children. The instruction also offered a detailed plan for classes with children on hot and rainy days [12, p. 138-139].

It is noteworthy that, in recommending the indicative lesson plan, the creators of the instruction did not blindly follow it, but only sought to give the guide "approximate concept of how to deal". The instruction required to conduct classes taking into account the age characteristics of children, without coercion, on the basis of free choice, interest. It was emphasized that "... there are no precise education plans in kindergarten, because kindergarten is not a school in which children are taught, and we can never change the kindergarten to school". The best method of education was determined by the method of projects. It was believed that the methods of M. Montessori and O. Decroly, which were used in permanent zakhoronky, "will not be used in the kindergarten" [12, p. 139].

The instruction also had directions for organizing performances, holidays in kindergartens, and the like.

It was the first program of activity of Ukrainian seasonal kindergartens aimed at organizing a unified system of educational work with pre-school children. Despite some omissions inherent in the general pedagogical thought of the time, it generally corresponded to the purpose and tasks of comprehensive education of pre-school children, facilitated the transformation of this type of pre-school institutions into important centers of the physical and spiritual development of children and their ethnization.

I. Blazhkevych was interested in the problems of parenting both as a mother and as a teacher. She published notes and short correspondence on the pages of "Woman's Fate", in which she advised to teach children the simplest homework, to entrust them with the care of rabbits and poultry [15, p. 20].

In "Cultural Family", published in "Self-Education" in 1934, the author raises important problems of social upbringing - about the relationships between a man and a woman in the family, about raising children - worthy citizens of their homeland: "It is a very important thing to have a solid line in the upbringing of [children]. What has been commanded - must be fulfilled, what was once forbidden - must be so. The mother who prefers to punish the child in the first place, and in a minute is sad herself to caress and fondle the child. For the second time, such a child does not know what is free and what is not free, what is being punished and what is praised for, and will do what he/she likes, often to the own and others' detriment. Such a mother loses respect of the child, because the child sees that the mother herself does not know what is free and what is not free". The author immediately makes an instructive conclusion: "As we can see, being a smart mother is not such an easy thing, so a mother must read a lot and take care of her education in general" [8, p. 106].

The above points out that in the 1920-s - early 1930$\mathrm{s}$ the appropriate organizational, methodologicaltheoretical basis for the activities of Ukrainian zakhoronky and kindergartens was established in Eastern Galicia. The most characteristic features of this process were: orientation of the theory and practice of preschooling of the region on the content dominants of the creative heritage of prominent representatives of national pedagogical thought, natives of the Dnieper Ukraine; active participation of women in the formation of organizational and theoretical-methodological foundations of national pre-school education; stable tendency to take into account the possibilities of Ukrainian institutions of guardianship, education and preparation of children for school as well as the peculiarities of functioning of society in the face of increasing oppression by the official Polish authorities.

The article "In the $50^{\text {th }}$ Anniversary of the First Ukrainian Zakhoronky" (1942) stated: "By the efforts of the "Native School" seasonal kindergartens were organized during summer work in the villages and towns. In that work, the Ukrainian national teachers took active part, directing the new kindergartens to the right way of educating and teaching the village pre-school children. Also, reading rooms of "Prosvita" and branches of "Union of Ukrainians" were keenly interested in the kindergarten business and with their cooperation the number of kindergartens increased from year to year [8, p. 106].

I. Blazhkevych paid attention to the competent selection of pedagogical staff for kindergartens. Among the recruitment criteria she has in the first place the love that is embedded in every woman. It "encourages the kindergarten teacher to become more familiar with preschool education; she will understand its importance, gain the will to know every child entrusted with her tutelage, will love these little children as relatives, will learn with them new games every time, and invent new games by herself", - wrote Ivanna Blazhkevych's granddaughter Iryna Rutylo [8, p. 107]. 
It should be noted that Ivanna Blazhkevych was convinced that the prospects of state building depend on the development of schooling: "bright future" lies through the quality education and it is necessary to start from the preschool education, and this process is continuous" [1, p. 2].

I. Blazhkevych, being convinced that it is education that would enable to build bright future in Ukraine, paid considerable attention to the economic education of preschoolers. At the same time, she considered economic activity of citizens as a significant factor in strengthening the state. She did not only promote cooperative ideas in Eastern Galicia, she was also the founder and the first chairperson of the cooperative commission at the Union of Ukrainian women in Lviv, the chairperson of the supervisory board of the district dairy and chief director of "Raifaisenka" in Denysiv, a long-time member of the board "Audit Union of Cooperatives in Lviv", a member of the supervisory board and director of the Podillia Union of Cooperatives in Ternopil [1; 16, p. 177].

I. Blazhkevych predicted that the cooperative movement would enable people to achieve well-being. In her autobiography, she stated, "based on cooperative movement we will get better destiny, the better destiny for the whole nation, we will bring happiness and wellbeing" [16, p. 178; 8].

Becoming a member of the Socialist Party in 1963 and a freelance correspondent I. Blazhkevych continued to assist in the setting up of kindergartens in the villages. In the archive of the house-museum many evidences of her petitions are stored - reviews from district committees, regional committees, from editorial boards about consideration of her letters, till the requirements for opening of permanent kindergartens, construction of premises for them in Denysiv and other surrounding villages were satisfied [8, p. 108]. In addition, she cared about the high quality of teaching staff in them, was indignant that there were educators who, avoiding work in the beet fields, went to work in kindergartens, having neither proper qualification, nor pedagogical abilities, nor the desire and love for children. She was also worried about the poor material base of the kindergartens: there were not enough toys, furniture, good food. In addressing these issues, I. Blazhkevych wrote articles in the newspaper. In addition, she took care of the aesthetics of the illustrations in the children's magazines "Baby" and "Barvinok".

Unfortunately, such a prominent figure has no proper respect in the history of pre-school pedagogy.

The study of modern textbooks, manuals (Z. Borysova, Z. Nahachevska, N. Salyha, I. Uliukaieva) for the students the history of pre-school pedagogy showed that the figure of Ivanna Blazhkevych, her educational and cultural-educational activities are not studied. And this is at a time when significant attention is paid to the contribution to the pre-school pedagogy of figures whose creativity is of no interest to contemporaries. Thus, there are articles about V. Belinskyi, M. Dobroliubov, N. Krupska and others in the textbook on the history of pre-school pedagogy ("Readings on the History of Pre-School Pedagogy (2004)"), however, there is not a single word about those people who founded Ukrainian pre-school institutions in Eastern Galicia [17].

Some educational and methodical works on the background of the development of Ukrainian preschooling cover the issues of activity of Galician educated women. We refer to the educational and methodical manual, authored and compiled by N. Salyha. It mentions I. Blazhkevych's activities. The author notes in particular: "At the origins of the theory and practice of public pre-school education were N. Kobrynska, K. Malytska, and I. Blazhkevych" [2, p. 58].

However, I. Blazhkevych's views on pre-school education should be reflected in more detail, since the interest to them is not only a reflection of the spirituality of society, but also the belief that it is only through the development of education that the level of economic growth and well-being of people can be enhanced.

The current state of pre-school education in Ukraine is defined as the stage of development between the old system of values, attitudes, traditions and the new, which is emerging, and is aims at providing optimal conditions for the education and upbringing of creative, active personality. In the $21^{\text {st }}$ century, new requirements have been put forward regarding the goals, objectives, structure and content of pre-school education, related to the current general globalization processes, changing worldview and values, Ukraine's desire to integrate into the European social-humanitarian and administrative space, preserving own achievements. Implementation of the pedagogical, cultural and creative achievements of Ukrainian educators of Eastern Galicia second half of the $19^{\text {th }}-$ beginning of the $20^{\text {th }}$ century is also relevant nowadays because we can trace clear parallels to contemporary realities: the need for changes that would ensure the development of a child, the upbringing of national-patriotic values. In this way, it is advisable to improve and expand the networks of institutions of different types, change the mode of their operation; implementation of modern technologies for active socialization of children, correction of their physical and mental development; newest innovative models of integrated education. Modernizing the content of preschool education requires defining clear methodological principles that take into account current world and European trends in its development and, at the same time, are based on the heritage of Ukrainian culture [18, p. 1].

\section{Conclusions}

Forming a new educational paradigm, it is important to use the following pedagogical ideas by I. Blazhkevych: - expansion of the network of pre-school institutions, creation of institutions of various types, including parttime;

- strengthening of national-patriotic upbringing in preschool education institutions (formation of love for the native land);

- formation of aesthetic tastes of children as a direction of media education by means of Ukrainian periodicals; 
- defining requirements for kindergarten teachers. We believe that it is expedient to develop Professional Standard "Kindergarten Teacher";

- early involvement of pre-school children in selfgovernment, in particular the distribution of tasks among pre-school children, in particular; this method of selfgovernment is advisable to use as a way of preventing bullying.

At the same time, the use of books authored by the Ukrainian writer Ivanna Blazhkevych, who wrote popular poetry for young children is relevant in the educational process of pre-school institutions.

In our opinion, the renewal of interest in the activity and creativity of I. Blazhkevych as one of the leading national figures on the part of pedagogues, parents, children, students-future specialists of pre-school education, reflection of the system of her work in textbooks and manuals on the history of pre-school pedagogy will become another important indicator of positive changes in the educational field of modern Ukraine. However, the idea of strengthening the Ukrainian state through the development of education, especially for the youngest children.

\section{References}

1. I. Blazhkevych, Dytiachyi sadok na seli v chasi litnikh robit (Kindergarten in the village during summer work). (Lviv, 1930)

2. N. Salyha, Istoriia doshkilnoi pedahohiky (History of Pre-School Pedagogy). (NAIR, Ivano-Frankivsk, 2014)

3. I.H. Uliukaieva, Istoriia doshkilnoi pedahohiky (History of Pre-school Pedagogy). (Disa plius, Kharkiv, 2015)

4. B. Melnychuk, V. Khoma, Blazhkevych Ivanna Omelianivna, in Ternopilskyi entsyklopedychnyi slovnyk, ed. by H. Yavorskyi et al. (Zbruch, Ternopil, 2004), p. 142

5. O.B. Hanusyn, Dissertation, Lviv Ivan Franko National University, 2018

6. Z.I. Nahachevska, Dissertation, Kyiv Taras Shevchenko University, 1995

7. I.Blazhkevych, Opovidannia (The story). (Svit dytyny, Lviv, 1937)

8. I. Rutylo, Ivanna Blazhkevych i doshkillia (Ivanna Blazhkevych and Preschooling). Scientific notes of TDPU, Series "Pedagogy" 11, 104-108 (2002)

9. M. Chorna, Diialnist Ivanny Blazhkevych u Podilskomu soiuzi kooperatyviv uprodovzh 20-30kh rokiv XX stolittia (Ivanna Blazhkevych's activity in Podillia union of cooperatives during 20-30-s years of the $\mathrm{XX}^{\text {th }}$ century). Visnyk Lvivskoi komertsiinoi akademii, Seriia: Humanitarni nauky $11(2013)$

10. I. Kuzma, Formuvannia mediahramotnosti ditei starshoho doshkilnoho viku: teoriia i tekhnolohiia (Formation of media literacy of older preschoolers: theory and technology). (Vector, Ternopil, 2019)
11. S. Rusova, Teoriia $i$ praktyka doshkilnoho vykhovannia (Theory and practice of preschool education). (Ukr. hromad. vyd. fond, Praha, 1924), p. 123

12. Z. I. Nahachevska, Ukrainske doshkillia v osvitnomu prostori Halychyny (kinets XIX st. - 1939 r.) (Ukrainian Preschool in the Educational Space of Halychyna (end of 19th century - 1939)). (NAIR, Ivano-Frankivsk, 2015)

13. I. Blazhkevych, Rukopysy narysiv: Pro ditei ta batkiv (Manuscripts of Essays: About Children and Parents), State archive of Ternopil region, f. P 3205, op. 1, cf. 32, 4 sheets

14. U Ternopoli vshanuvaly vidomu ukrainsku dytiachu pysmennytsiu Ivannu Blazhkevych (The famous Ukrainian children's writer Ivanna Blazhkevych was honored in Ternopil) (2016), https://day.kyiv.ua/uk/news/081016-u-ternopolivshanuvaly-vidomu-ukrayinsku-dytyachupysmennycyu-ivannu-blazhkevych. Accessed 28 Nov 2019.

15. Knyha pamiati Ivanny Blazhkevych (Book of memory of Ivanna Blazhkevych). Halych 32 (1991)

16. M. Chorna, Kooperatyvna diialnist Ivanny Blazhkevych u Skhidnii Halychyni (Cooperative Activity of Ivanna Blazhkevych in Eastern Galicia). Scientific Notes of Ternopil Volodymyr Hnatiuk National Pedagogical University, Series "History" 1, 96-103 (2012)

17. Z.N. Borysova (ed.), Khrestomatiia $z$ istorii doshkilnoi pedahohiky (Readings on the History of Pre-School Pedagogy). (Higher School, Kyiv, 2004)

18. N.V. Huk, Derzhavna polityka rozvytku doshkilnoho vykhovannia $v$ Ukraini (State policy for development of kindergarten in Ukraine) (2014), http://www.kbuapa.kharkov.ua/e-book/conf/20143/doc/3/06.pdf. Accessed 28 Nov 2019 